\title{
eHealth Research from the User's Perspective
}

\author{
Bradford W. Hesse, PhD, Ben Shneiderman, PhD
}

Abstract: The application of information technology (IT) to issues of healthcare delivery has had a long and tortuous history in the United States. Within the field of eHealth, vanguard applications of advanced computing techniques, such as applications in artificial intelligence or expert systems, have languished in spite of a track record of scholarly publication and decisional accuracy. The problem is one of purpose, of asking the right questions for the science to solve. Historically, many computer science pioneers have been tempted to ask "what can the computer do?" New advances in eHealth are prompting developers to ask "what can people do?" How can eHealth take part in national goals for healthcare reform to empower relationships between healthcare professionals and patients, healthcare teams and families, and hospitals and communities to improve health equitably throughout the population? To do this, eHealth researchers must combine best evidence from the user sciences (human factors engineering, human-computer interaction, psychology, and usability) with best evidence in medicine to create transformational improvements in the quality of care that medicine offers. These improvements should follow recommendations from the Institute of Medicine to create a healthcare system that is (1) safe, (2) effective (evidence based), (3) patient centered, and (4) timely. Relying on the eHealth researcher's intuitive grasp of systems issues, improvements should be made with considerations of users and beneficiaries at the individual (patient-physician), group (family-staff), community, and broad environmental levels.

(Am J Prev Med 2007;32(5S):S97-S103) @ 2007 American Journal of Preventive Medicine

\section{Introduction}

$\mathrm{T}$ he application of information technology (IT) to issues of personal health and health care has had a long and surprisingly complex history within the United States. Soon after the first mainframe computer systems began automating record keeping, hospitals began applying IT to the tasks of billing and financial record keeping. ${ }^{1}$ Yet, in spite of an early application of IT to administrative and actuarial tasks, the challenge of developing a consistent, interoperable system for transporting patients' medical records across healthcare systems has been an elusive and seemingly intractable goal. ${ }^{2}$ Reasons given for delays in this and other areas of health IT include grappling with competing incentive structures, dealing with issues of standardization, meshing with time-pressured workflows, ensuring privacy, and creating systems that are useful and usable to data producers as well as data users. ${ }^{3-6}$ In short, reasons given have not focused as much on inadequacies of the technology, but more on the interface between the social and the technical, that is, between users and the system. ${ }^{7}$

From the Division of Cancer Control and Population Sciences, National Cancer Institute (Hesse), Bethesda, Maryland; and Department of Computer Science, University of Maryland (Shneiderman), College Park, Maryland

Address correspondence and reprint requests to: Bradford W. Hesse, PhD, National Cancer Institute, 6130 Executive Blvd., MSC 7365, Bethesda MD 20892-7365. E-mail: hesseb@mail.nih.gov.

\section{Asking What Computers Can Do}

In the same vein, the field of medical informatics has produced some of the most advanced computing technologies to be applied in real-world settings. Applications of artificial intelligence to medicine in the 1980s produced such vanguard systems as the rule-based MYCIN expert system at Stanford University, ${ }^{8}$ the Iliad, ${ }^{9}$ HELP $^{10}$ resources at the University of Utah, and the Quick Medical Reference (QMR) ${ }^{11}$ physician aid at the University of Pittsburgh. Yet, after years of successful testing and scholarly publication many of the most sophisticated diagnostic systems-at least as originally scoped-have fallen into disuse. ${ }^{1,12}$ Users reported feeling uncomfortable relying on the decisional recommendations of an opaque, black box computer system no matter how much more accurate the system's decisions were compared to those of actual clinicians. ${ }^{12}$

In many respects, the hope and hype of IT applied to health care reflect the lessons learned from computer science more generally. The field of computer science is littered with applications that, although technologically superior, have failed to find a following among discriminating users. From an historical perspective, the problem has been one of purpose and focus-that is, of asking the right question for the science to solve. The field of artificial intelligence is a good example. Early applications followed a model of automating human processes by creating applications that mim- 
icked what humans do. The motivation stemmed in part from an industrial view of technology in which machinery was engineered with the explicit purpose of replacing the physical labor of factory workers, thereby saving money through reductions in personnel costs. ${ }^{13}$ It also stemmed from an unabashed, romantic notion of creating a future inhabited by smart, thinking machines. ${ }^{14}$ Quite simply, the science of artificial intelligence often found itself following the art of science fiction. ${ }^{15}$

Later applications-the ones that survivedchanged their focus. Rather than supplant human capabilities, the newer applications were focused on supplementing or complementing the information processing abilities of their operators. ${ }^{16}$ The lexical applications embedded in many popular word processing systems are a good example. These systems run unobtrusively in the background but offer a comfortable safety net to writers in checking for spelling errors, monitoring for punctuation, and offering suggestions for grammatical improvements. In a similar way, reminder systems in hospitals can use advanced computing techniques to keep a patient's therapeutic regimen on track $^{17}$ or to protect healthcare professionals from prescribing medications with documented interactions. ${ }^{18}$ As one commentator put it, these new applications serve to "informate" rather than "automate" human processes. They add value precisely because their routines improve on human performance, and do not try to replace it. ${ }^{13}$

\section{Asking What People Can Do}

In the field of eHealth research, as with research in other vital areas of computer applications, major efforts are under way to achieve a new stage of maturation. During the pioneering days of eHealth, the question was often about what the computer could do. During the next phase, crucial questions concern what people can do. How can advanced computing and telecommunications be used in conjunction with existing systems of care to ensure that people live longer and higher quality lives? David Brailer, former National Health Information Technology Coordinator for the U.S. Department of Health and Human Services, said it this way: "Everyone thought IT was about computers, but we've refined that to say that IT is about health careit's about the experience we really have."19

\section{The eHealth Experience}

The notion of eHealth gained currency in the 1990s at a time when public expansion of the Internet promised to transform information exchange, product acquisition, and service delivery. Research on the benefits of using wide area network technologies, at least among scientists and technical administrators, had suggested that distributed computing could bring people and resources together in ways that had not been seen before. ${ }^{20,21}$ eHealth, like eCommerce, and eGovernment, promised to transform the status quo by breaking down barriers of time and place. This mix of technology, as well as the entrepreneurial and idealistic spirit of taking benefits directly to consumers, remains inseparably mixed in definitions of eHealth today. ${ }^{22,23}$

For medical informaticians and policymakers, the promise of eHealth opened up a capacity to link advances in medical information technology to the advantages promised by an emerging national health information infrastructure. ${ }^{24}$ This led to a number of pioneering efforts to bring advanced technologies, incubated previously within hospital settings, onto the web for patients and practitioners to use. Complex decision support technologies were mounted on the web for patients' use. Large-scale bibliographic databases were pushed to the public.

\section{Public Reactions}

Reactions from the public to this push were mixed, and did not conform neatly to expectations. ${ }^{25}$ In 1997 , when speculation was high and innovation outpaced demand, only $22.2 \%$ of the U.S. population aged 3 years and older reported having access to the Internet. ${ }^{26}$ By 2003, after the "dot com bust" was predicted to dampen consumer enthusiasm, Internet penetration soared to the point at which an estimated $63 \%$ of adults aged 18 years and older were online. ${ }^{27,28}$ By 2005, the Internet had become part of the "new normal," that is, it had become part of the constellation of everyday media and resources that people use as supports in their ongoing busy lives. ${ }^{29}$

As early as 1999, surveys had revealed that health information seeking was a frequent and common practice on the Internet. ${ }^{30}$ What people often found online, though, was a cacophony of mixed messages and information sites of unequal quality and usefulness. Visitors to commercial sites were wary of ulterior motives and unfounded claims ${ }^{31,32}$; visitors to government and academic sites were inundated with highly technical language and raw data with little synthesis or integration. ${ }^{33,34}$

In an age of abundant health information, consumers reported feeling confused and perplexed. ${ }^{35}$ Estimates suggested that in 2003 more than three quarters of the general adult population would endorse the statement that there were too many prevention recommendations in the area of cancer to know which ones to follow. ${ }^{36}$ About half of the population reported looking for information on cancer either for themselves or for others, and out of that group the Internet was the first place they looked. At the same time, a majority of Americans reported having greater confidence in their physicians than in the Internet. ${ }^{27}$ Newer results indicate 
that the credibility differences between physicians and the Internet may be widening, with trust in physicians trending upwards and trust in the Internet trending downwards. ${ }^{37}$

\section{Health Care in the Information Age}

While the strain of keeping up with the explosion of information on the web is challenging for consumers, the task of staying current on the tsunami of mounting medical information is even more challenging for healthcare professionals. In 2004, the National Library of Medicine reported that it added more than half a million $(571,000)$ new references to its online bibliographic database. ${ }^{38}$ By some estimates, a general internist would have to read 20 articles a day 365 days a year just to keep current on relevant medical knowledge. ${ }^{39}$

Added to the burden of keeping current on research is the strain of keeping up with an increasingly mobile patient base. The goal of maintaining a "life-span" perspective on a patient's health ${ }^{19}$ is complicated by the challenge of keeping records current on a lifetime's worth of medical history, laboratory results, specialists' reports, pharmaceutical records, adverse reactions, and psychosocial indicators. ${ }^{40}$ Indeed, combining the best of current medical knowledge with a patient's own historical data in an age of "personalized medicine," will be next to impossible without the assistance of health information technology. Without an electronic infrastructure to guarantee safekeeping and backup of patients' data, it is impossible to guarantee continuity of care for some of the most vulnerable in the population ${ }^{42}$ - a crisis acutely manifest in the 2005 Hurricane Katrina disaster. ${ }^{43}$

As medical technology advances and the health information environment becomes more complex, health care becomes more vulnerable to error. Health systems analysts have estimated that up to 98,000 avoidable deaths per year occur because of a lack of supportive safety mechanisms in pharmacy, surgery, hospital care, and outpatient care. ${ }^{40,44}$ An analysis of medical charts for women presenting with late-stage cervical cancer within one medical system revealed that more than half of the deaths could have been avoided if the system had kept women up-to-date on routine Papanicolaou test screens. ${ }^{45}$ The good news from the patient's perspective is that advances in biomedical science in the 20th century may have nearly doubled life expectancy; the bad news is that the healthcare system has grown complex, reactive, and potentially dangerous. ${ }^{46}$

Clearly, health information technologies will, and must, be part of the solution to guarantee that safeguards are engineered into the environment in which health care takes place. ${ }^{40,47,48}$ It must be remembered, however, that the science of informatics is the science of sociotechnical systems, ${ }^{49}$ which in turn, is the science

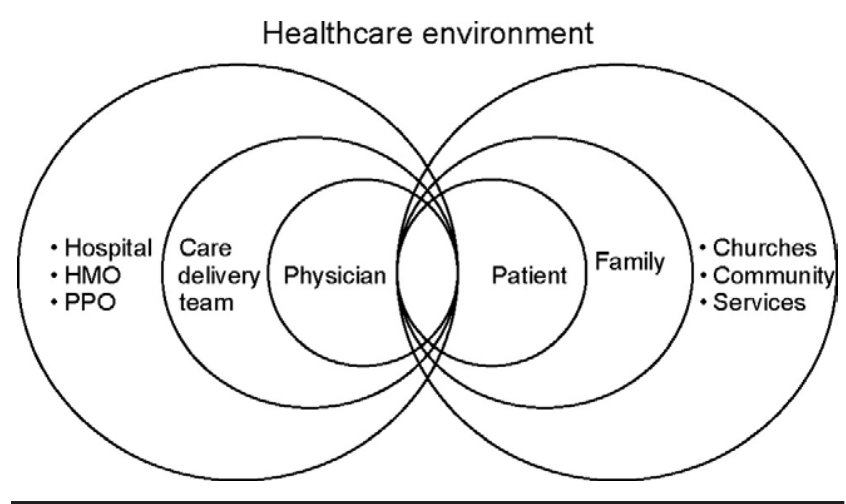

Figure 1. Users within the healthcare system as described in the Institute of Medicine's prescriptive framework for health system reform.

of "people, tools, and conversations" working in synchrony to achieve common goals. ${ }^{7}$ eHealth research must become part of the system of reform that will link evidence-based medical practices to national standards of equity, safety, usability, and patient-centeredness. It must work in tandem with physicians, nursing staff, office staff, and other links in the healthcare chain to comprise a safety net of support for patients.

\section{Users in an eHealth-Enabled System}

The Institute of Medicine (IOM) presented a framework for healthcare reform in its report titled, Crossing the Quality Chasm: A New Healthcare System for the 21st Century. In Figure 1, we take the users who are described in that report and present them graphically as two interlocking sets of concentric circles. At the center of the figure is the direct interaction between the healthcare professional and each individual patient. This is the nexus of the healthcare relationship and symbolizes the direct point of accountability between an individual's own self-management and the healthcare provider's training and recommendations.

Surrounding the provider-patient link are concentric circles of expanding group and systems support. On the healthcare provider side, the individual practitioner works as one member of a coordinated "microunit" of care: office staff, surgical teams, long-term care teams, and so on. The microunit is in turn embedded within larger enabling systems, including hospitals, health maintenance organizations, preferred provider organizations, and others. On the public side, the patient is surrounded by family, friends, and neighbors as the most immediate circle of support. Public interactions occur within the greater sphere of a functioning community, with churches, businesses, civic groups, and social services. Both sides of the relationship are in turn embedded within a larger context of policies, regulations, and incentives. 
Table 1. Health system goals as a function of level of user

\begin{tabular}{|c|c|c|c|c|}
\hline & \multicolumn{4}{|c|}{ Health system goals } \\
\hline Patient & $\begin{array}{l}\text { High-quality care free } \\
\text { of complications }\end{array}$ & $\begin{array}{l}\text { Evidence-based } \\
\text { standards of care }\end{array}$ & $\begin{array}{l}\text { Ongoing support for } \\
\text { life goals, values }\end{array}$ & $\begin{array}{l}\text { Reliable service when } \\
\text { needed }\end{array}$ \\
\hline Physician & $\begin{array}{l}\text { System protections } \\
\text { against error }\end{array}$ & $\begin{array}{l}\text { Knowledge management } \\
\text { for best practice }\end{array}$ & $\begin{array}{l}\text { Support for tracking, } \\
\text { personalization }\end{array}$ & $\begin{array}{l}\text { Work flow engineered } \\
\text { for proactive care }\end{array}$ \\
\hline Family, friends & $\begin{array}{l}\text { Caregivers help } \\
\text { monitor for risk }\end{array}$ & $\begin{array}{l}\text { Access to effective } \\
\text { support tools }\end{array}$ & $\begin{array}{l}\text { Support roles for } \\
\text { caregivers clear, } \\
\text { defined }\end{array}$ & $\begin{array}{l}\text { System responsiveness } \\
\text { for caregivers }\end{array}$ \\
\hline Microunits of care & $\begin{array}{l}\text { Team delivery } \\
\text { reduces error }\end{array}$ & $\begin{array}{l}\text { Consistent application } \\
\text { of guidelines }\end{array}$ & $\begin{array}{l}\text { Team awareness of } \\
\text { patient needs }\end{array}$ & $\begin{array}{l}\text { Enhanced } \\
\text { coordination }\end{array}$ \\
\hline Community & $\begin{array}{l}\text { Monitoring for } \\
\text { quality assurance }\end{array}$ & $\begin{array}{l}\text { Research-tested } \\
\text { community } \\
\text { intervention }\end{array}$ & $\begin{array}{l}\text { Identifying and } \\
\text { meeting local } \\
\text { needs }\end{array}$ & $\begin{array}{l}\text { Efficiency through } \\
\text { partnering }\end{array}$ \\
\hline $\begin{array}{l}\text { Organizations for care } \\
\text { (hospitals, HMOs) }\end{array}$ & $\begin{array}{l}\text { Safety as a system } \\
\text { property }\end{array}$ & Data based management & $\begin{array}{l}\text { Interoperable } \\
\text { systems for patient } \\
\text { support }\end{array}$ & $\begin{array}{l}\text { Continuous quality } \\
\text { improvement }\end{array}$ \\
\hline Healthcare context & Culture of safety & $\begin{array}{l}\text { Policy informed by } \\
\text { evidence }\end{array}$ & $\begin{array}{l}\text { National standards } \\
\text { for transportability }\end{array}$ & $\begin{array}{l}\text { Efficient delivery and } \\
\text { reimbursement of } \\
\text { care }\end{array}$ \\
\hline
\end{tabular}

\section{Tasks, Goals, and Objectives}

In Table 1, we juxtapose types of users against the major tasks, goals, and objectives outlined in the IOM framework. ${ }^{50}$ We have selected four overarching goals as being especially relevant to a discussion of eHealth and have listed them as labels for the four columns in the table. At the junction of row and column we indicate how the goals and objectives of the new healthcare framework become relevant across levels of users. The individual cells represent the particular "use case scenarios" that the eHealth-enabled system must support.

Safety. A core tenet of the IOM's prescriptive framework is that safety must be made an inherent attribute of the system. ${ }^{40,50}$ If information is too complex to understand, especially under periods of duress or high cognitive load, then the interface to that information must be simplified. If critical events fail to occur because of lapses in memory, then the system must monitor for completion of those events and send status reminders as appropriate to decision makers until they are fulfilled or dismissed. The principle is to make the healthcare system foolproof by designing the interface between components to be consistent, predictable, and controllable by all of its users. ${ }^{51}$

Throughout the first column in Table 1, we emphasize the theme of safety as a system property for eHealth across levels of users. On the delivery side, a coordinated system of safeguards should allow teams of healthcare professionals to work interdependently in a system that promotes safe practices and encourages continuous quality improvement. Informatics will offer a seamless level of information support on this side, but the technologies should be introduced into the system only after following a rigorous schedule of iterative usability testing and formative evaluation. ${ }^{52}$ "Humancentered" testing methods applied within the context of "bench-to-bedside" research should be as important to the informatics enterprise as randomized clinical trials are for the introduction of new pharmaceutical agents. $^{53}$

On the public side, self-empowered patients and their caregivers must be considered as crucial elements of care in the overall system. Day-to-day adherence to medical regimens takes place in the home, selfmonitoring for early symptoms takes place at a personal level, and the preponderance of crucial and vital decision making takes place between family members. ${ }^{54-59}$ It is within these personal patient spheres that health care actually begins and often ends. Every tool and every connective network meant to support these spheres must be engineered with the same strict set of human factors standards and testing that will govern the development of safe systems within hospital settings. This is currently not the case. Something as simple as the computerized label printed on a pill bottle is usually so jargon laden, and so functionally imprecise, that patients are at serious risk for error in the home. ${ }^{60}$ Patients and their families must be engineered into the system as a first line of defense against potential errors, not the last. ${ }^{58}$ 
Effectiveness. Medicine extended the life span of individuals in the 20th century by moving from a practice of art based on speculation, to a practice of science based on evidence. Bringing the science and evidence of medicine into the care process at the right times is another high-priority challenge in the IOM's prescription.

Throughout the course of the 20th century, the assumption behind medical training was that the best way to transmit knowledge from its source to its use in patient care was "to first load the knowledge into human minds ... and then expect those minds, at great expense, to apply the knowledge to those who need it." ${ }^{1}$ Designing from the user's perspective takes a different orientation. ${ }^{62}$ It embraces the notion that effective decision making is a product of knowledge contained in the mind as well as knowledge stored in the environment. ${ }^{63}$ Taking this perspective, the emphasis shifts from personal heroics to creating a system of knowledge to guide evidence-based delivery, a shift that has been shown to yield significant improvements in patient outcomes and reductions in costs. ${ }^{64,65}$

Another area of productive research is the translation of nonlinear, high-density information fields into meaningful displays that can be quickly assimilated through visual inspection. ${ }^{66,67}$ Work being conducted in the Human-Computer Interaction Laboratory at the University of Maryland is producing a new look at the task of combining all of the relevant information needed for a clinical encounter into single, highly effective visual displays. ${ }^{66,68}$ Work being funded by the National Cancer Institute is enabling comparable approaches for displaying personal risk information to patients visually, with significant yields in comprehension and usefulness. ${ }^{69-71}$

Patient-centeredness. With all the discussion of multiple users, from physicians to care units to hospitals, and from patients to caregivers, the ultimate goal of the healthcare system is to improve patient outcomes. All of the tools, conversations, and decisions that take place within a healthcare system must be measured against the benchmark of patient need in order to achieve systemwide objectives of safety and effectiveness. ${ }^{54,55,59}$

One aspect of patient-centeredness is customized care. ${ }^{72}$ Advances in biomarker detection, ${ }^{73}$ targeted pharmacogenetics, ${ }^{74}$ and tailored communication ${ }^{75}$ are making it possible to focus care individually on the specific needs of each patient. eHealth applications will be part of this effort as they assist in providing the right information, to the right person, at the right time. ${ }^{76}$ Caution must be taken to incorporate evidence from the existing literature on human-computer interaction when doing this. Many theoretically elegant interfaces (adaptive interfaces, social agents, expert systems) have failed in real-world settings. When measured against the benchmark of user goals, the systems were perceived as being unpredictable and inconsistent. ${ }^{15}$

Another aspect of patient-centeredness, which may be called population-centeredness, is the goal of extending the reach of medical knowledge to serve a diversity of beneficiaries in an equitable fashion. This means that the public interface to medicine, from instructions on a prescription bottle to a web-based portal for access to personal health information, must be equitably accessible to all users. One strategy for accomplishing that goal in eHealth is to adopt the principle of universal design. ${ }^{15,77}$ Under this principle, the structured environment is created to be equally accessible by all users, regardless of experience level or physical ability. A simple example in the physical world is the presence of "curb cuts" at the entrance to stores and office buildings, or the inclined ramps cut into sidewalks that provide easy passage for those in wheelchairs as well as anyone wheeling a shopping cart or set of heavy luggage.

Curb cuts do not just work in the physical environment, but with a little forethought can be built into the virtual eHealth environment. ${ }^{78}$ Adherence to the standards set by section 508 of the Rehabilitation Act (see www.access-board.gov/508.htm) will ensure that websites are compliant with text-reading software for users who are visually impaired and will not get in the way of a sighted user's ability to interact with the site. ${ }^{79}$ Likewise, following prescriptions from the "plain language" movement will help ensure that labels, instructions, and health-related content in eHealth applications are equally accessible to all users regardless of educational background or medical experience. ${ }^{80,81}$ Guideline documents ${ }^{82,83}$ as well as automated assessment tools ${ }^{84}$ are readily available to assist the eHealth designer in making applications universally usable by a diversity of audiences. Formative usability testing, conducted across the full range of expected user types, will also help ensure that the final product is equally accessible to a broad range of users. ${ }^{83}$

Timeliness. It has been said that time is the currency of the information age. Yet, one of the "problems with computers" $" 85$ is a failure to account for the accumulated effect of small temporal disruptions on the overall performance of human systems. ${ }^{85-87}$ Consider the cumulative impact of dealing with pop-up ads on the web, or spending an inordinate amount of time being shuffled from one multilayered telephone answering system to another before being connected to an advice nurse at a hospital. The error is one of myopia, argued Zuboff and Maxmin, ${ }^{88}$ as engineers focus solutions on single transactions without considering the impact of multiple interactions on trust and relationships.

The IOM emphasized that a patient-centered healthcare system must move away from a transaction-based management environment, to an environment that 
fosters "healing relationships" over time. To do this, all components of the system must be coordinated to provide levels of "deep support" 88 for patients and their caregivers. Coordinated eHealth technologies can and should be developed to keep track of the individual needs of patients, and to ensure that all relevant members of the healthcare team, including the patients themselves, are notified in a timely manner. With an interoperable system of electronic medical records in place, ${ }^{65}$ eHealth applications can be built to encourage prevention and health maintenance, and to catch potential treatment errors early before any real harm is done. ${ }^{89-91}$

\section{Conclusion}

We are at a turning point in eHealth research. Taken down the right path-if we ask the right questioneHealth will become part of the solution in turning the tide of medical errors and extending quality of life equitably throughout the population. Taken down the wrong path-if we ask the wrong questions-eHealth will escalate the crisis in health care as only computers can do. ${ }^{85}$

Fortunately, there is a way through the conundrum. The path lies in merging the science of evidence-based medicine with the practice of user-centered research. This is a transdisciplinary ${ }^{92}$ union, bringing the knowledge bases of a rapidly advancing biomedical research enterprise into synchrony with a burgeoning evidence base in the cognitive and computational sciences. ${ }^{15,83,93}$ The union is needed now more than ever, and cannot be taken for granted. Case studies from the diffusion of innovations highlight what happens when less-thanoptimal designs catch the "tipping point" ${ }^{4}$ of diffusion before they have been optimized for user needs and constraints. The results, in the most benign sense, can be an ascendancy of mediocrity (consider the seemingly intractable diffusion of the QWERTY keyboard); results in the most severe case can cost lives. By riveting technology development on the questions that matter, eHealth researchers can provide a feedback loop into health system reform. More importantly, eHealth researchers can help to accelerate progress for improving lives, which is the metric that matters most from the user's perspective.

This literature review was funded by the National Cancer Institute.

No financial conflict of interest was reported by the authors of this paper.

\section{References}

1. Shortliffe EH. Medical informatics: computer applications in health care and biomedicine. 2nd ed. New York: Springer, 2001.
2. Shortliffe EH. Strategic action in health information technology: why the obvious has taken so long. Health Aff (Millwood) 2005;24:1222-33.

3. Wears RL, Berg M. Computer technology and clinical work: still waiting for Godot. JAMA 2005;293:1261-3.

4. Malhotra Y, Galletta DF. Building systems that users want to use. Commun ACM 2004;47:88-94.

5. Heeks R. Health information systems: failure, success and improvisation Int J Med Inform 2006;75:125-37.

6. Kaplan B. Addressing organizational issues into the evaluation of medical systems. J Am Med Inform Assoc 1997;4:94-101.

7. Coiera E. Four rules for the reinvention of health care. BMJ 2004; 328:1197-9.

8. Buchanan BG, Shortliffe EH. Rule-based expert systems: the MYCIN experiments of the Stanford Heuristic Programming Project. Reading MA: Addison-Wesley, 1984.

9. Warner HR Jr, Bouhaddou O. Innovation review: Iliad-a medical diagnostic support program. Top Health Inform Manag 1994;14:51-8.

10. Haug PJ, Gardner RM, Tate KE, Evans RS, East TD, Kuperman G, et al. Decision support in medicine: examples from the HELP system. Comput Biomed Res 1994;27:396-418.

11. Miller R, Masarie FE, Myers JD. Quick medical reference (QMR) for diagnostic assistance. MD Comput 1986;3:34-48.

12. Miller RA. Medical diagnostic decision support systems-past, present, and future: a threaded bibliography and brief commentary. J Am Med Inform Assoc 1994;1:8-27.

13. Zuboff S. In the age of the smart machine: the future of work and power. New York: Basic Books, 1988.

14. Stork DG, editor. HAL's legacy: 2001's computer as dream and reality. Cambridge MA: MIT Press, 1997.

15. Shneiderman B. Leonardo's laptop: human needs and the new computing technologies. Cambridge MA: MIT Press, 2002.

16. Hesse BW. Harnessing the power of an intelligent health environment in cancer control. Stud Health Technol Inform 2005;118:159-76.

17. Balas EA, Weingarten S, Garb CT, Blumenthal D, Boren SA, Brown GD. Improving preventive care by prompting physicians. Arch Intern Med 2000;160:301-8.

18. Kuperman GJ, Bobb AM, Payne T, et al. Medication-related clinical decision support in computerized provider order entry systems: a review. J Am Med Inform Assoc 2007;14:29-40.

19. Brailer D. Action through collaboration: a conversation with David Brailer. Health Aff (Millwood) 2005;24:1150-7.

20. Hesse BW, Sproull L, Kiesler SB, Walsh JP. Returns to science: computer networks in oceanography. Commun ACM 1993;36:90-101.

21. Sproull L, Kiesler S. Connections: new ways of working in the networked organization. Cambridge MA: MIT Press, 1991.

22. Oh H, Rizo C, Enkin M, Jadad A. What is eHealth? A systematic review of published definitions. World Hosp Health Serv 2005;41:32-40.

23. Eysenbach G. What is e-health? J Med Internet Res 2001;3:E20.

24. Yasnoff WA, Humphreys BL, Overhage JM, et al. A consensus action agenda for achieving the national health information infrastructure. J Am Med Inform Assoc 2004;11:332-8.

25. Eysenbach G, Kummervold PE. "Is cybermedicine killing you?"-The story of a Cochrane disaster. J Med Internet Res 2005;7:e21.

26. Office of Disease Prevention and Health Promotion. Communicating health: priorities and strategies for progress. Rockville MD: U.S. Department of Health and Human Services, 2003.

27. Hesse BW, Nelson DE, Kreps GL, Croyle RT, Arora NK, Rimer BK, et al. Trust and sources of health information. The impact of the Internet and its implications for health care providers: findings from the first Health Information National Trends Survey. Arch Intern Med 2005;165:2618-24.

28. Madden M. Online pursuits: the changing picture of who's online and what they do. Washington DC: Pew Research Center, 2003.

29. Pew Research Center. Trends 2005: information for the public interest. Washington DC: Pew Research Center 2005.

30. Rice RE. The Internet and health communication: a framework of experiences. In: Rice RE, Katz JE, eds. The Internet and health communication: experiences and expectations. Thousand Oaks CA: Sage, 2001:5-46.

31. Gustafson DH, Robinson TN, Ansley D, Adler L, Brennan PF. Consumers and evaluation of interactive health communication applications: the Science Panel on Interactive Communication and Health. Am J Prev Med 1999;16:23-9.

32. Eng TR, Gustafson DH. Wired for health and well-being: the emergence of interactive health communication. Washington DC: Science Panel on Interactive Communication and Health, U.S. Dept. of Health and Human Services, 1999. 
33. Berland GK, Elliott MN, Morales LS, et al. Health information on the Internet: accessibility, quality, and readability in English and Spanish. JAMA 2001;285:2612-21.

34. Shenk D. Data smog: surviving the information glut. San Francisco: Harper Edge, 1997.

35. Arora NK, Hesse BW, Rimer BK, Viswanath K, Clayman M, Croyle RT. The informed patient: struggling to stay afloat in a sea of cancer-related information. J Gen Internal Med. Accepted for publication.

36. Han P, Moser RP, Klein WM. Perceived ambiguity about cancer prevention recommendations: relationship to perceptions of cancer preventability, risk, and worry. J Health Commun 2006;11 (suppl 1):51-69.

37. Hesse BW. Identifying consumer needs for health information. Paper presented at MedNet conference, Toronto, Canada, October 2006.

38. National Library of Medicine. Fact sheet Medline. Bethesda MD: National Institutes of Health, 2005.

39. Shaneyfelt TM. Building bridges to quality. JAMA 2001;286:2600-1.

40. Institute of Medicine, Committee on Quality of Health Care in America. Crossing the quality chasm: a new health system for the 21st century. Washington DC: National Academy Press, 2001.

41. Culliton BJ. Extracting knowledge from science: a conversation with Elias Zerhouni. Health Aff (Millwood) 2006;25:w94-103.

42. Hewitt ME, Greenfield S, Stovall E, National Cancer Policy Board. From cancer patient to cancer survivor: lost in transition. Washington DC: National Academies Press, 2006.

43. Conn J. IT systems survive Katrina. Hospitals with EMRs able to retrieve patient data. Mod Healthcare 2005;35:12-4.

44. Leape LL, Berwick DM. Five years after To Err Is Human: what have we learned? JAMA 2005;293:2384-90.

45. Leyden WA, Manos MM, Geiger AM, et al. Cervical cancer in women with comprehensive health care access: attributable factors in the screening process. J Natl Cancer Inst 2005;97:675-83.

46. Chantler C. The role and education of doctors in the delivery of health care. Lancet 1999;353:1178-81.

47. Ortiz E, Meyer G, Burstin H. The role of clinical informatics in the Agency for Healthcare Research and Quality's efforts to improve patient safety. In: Proceedings of AMIA Symposium, Washington DC, November 2001: 508-12.

48. Savitz L. Envisioning safer healthcare. Healthc Pap 2004;5:69-74, discussion $82-4$.

49. Pava CHP. Managing new office technology: an organizational strategy. New York: Free Press; London: Collier Macmillan, 1983.

50. Berwick DM. A user's manual for the IOM's "Quality Chasm" report. Health Aff (Millwood) 2002;21:80-90.

51. James BC. Making it easy to do it right. N Engl J Med 2001;345:991-3.

52. Nielsen J. Usability engineering. Boston: Academic Press, 1993.

53. Cimino JJ, Patel VL, Kushniruk AW. Studying the human-computerterminology interface. J Am Med Inform Assoc 2001;8:163-73.

54. Epstein RM. The science of patient-centered care. J Fam Pract 2000; 49:805-7.

55. Epstein RM, Franks P, Fiscella K, et al. Measuring patient-centered communication in patient-physician consultations: theoretical and practical issues. Soc Sci Med 2005;61:1516-28.

56. Schweikhart SB. Reengineering the work of caregivers: role redefinition, team structures, and organizational redesign. Hosp Health Serv Adm 1996;41:19-36.

57. Gustafson DH, McTavish FM, Boberg E, et al. Empowering patients using computer based health support systems. Qual Health Care 1999;8:49-56.

58. Gustafson D. Engineering the patient and family into the patient care team. In: Proctor PR, Compton WD, Grossman JH, Fanjiang G, eds. Building a better delivery system: a new engineering/health care partnership. Washington DC: National Academies of Science, 2005:125-8.

59. Arora NK. Interacting with cancer patients: the significance of physicians' communication behavior. Soc Sci Med 2003;57:791-806.

60. Parker RM, Gazmararian JA. Health literacy: essential for health communication. J Health Commun 2003;1 (suppl 8):116-8.

61. Weed L. Opening the black box of clinical judgment-an overview. BMJ 1999;319:1279.

62. Norman DA, Draper SW. User-centered system design: new perspectives on human-computer interaction. Hillsdale NJ: L. Erlbaum Associates, 1986.

63. Norman DA. The design of everyday things. New York: Basic Books, 2002.

64. James BC. Implementing practice guidelines through clinical quality improvement. Front Health Serv Manag 1993;10:3-37, discussion 54-6.

65. James B. E-Health: steps on the road to interoperability. Health Aff (Millwood) 2005
66. Bederson B, Shneiderman B. The craft of information visualization: readings and reflections. Amsterdam, Boston: Morgan Kaufmann, 2003.

67. Card SK, Mackinlay JD, Shneiderman B. Readings in information visualization: using vision to think. San Francisco: Morgan Kaufmann Publishers, 1999.

68. Plaisant C, Mushlin R, Snyder A, Li J, Heller D, Shneiderman B. LifeLines: using visualization to enhance navigation and analysis of patient records. Paper presented at American Medical Informatic Association Annual Fall Symposium, Orlando FL, 1998.

69. Lipkus IM, Hollands JG. The visual communication of risk. J Natl Cancer Inst Monogr 1999:149-63.

70. Lipkus IM, Klein WM, Rimer BK. Communicating breast cancer risks to women using different formats. Cancer Epidemiol Biomarkers Prey 2001;10:895-8.

71. Gail MH, Brinton LA, Byar DP, et al. Projecting individualized probabilities of developing breast cancer for white females who are being examined annually. J Natl Cancer Inst 1989;81:1879-86.

72. Rimer BK, Conaway M, Lyna P, Glassman B, Yarnall KS, Lipkus I, et al. The impact of tailored interventions on a community health center population. Patient Educ Couns 1999;37:125-40.

73. Veenstra TD, Conrads TP, Hood BL, Avellino AM, Ellenbogen RG, Morrison RS. Biomarkers: mining the biofluid proteome. Mol Cell Proteomics 2005;4:409-18.

74. Ross JS, Schenkein DP, Pietrusko R, et al. Targeted therapies for cancer 2004. Am J Clin Pathol 2004;122:598-609.

75. Kreuter MW, Wray RJ. Tailored and targeted health communication: strategies for enhancing information relevance. Am J Health Behav 2003; 27(suppl 3):S227-32.

76. Suggs LS. A 10-year retrospective of research in new technologies for health communication. J Health Commun 2006;11:61-74.

77. Iezzoni LI. Toward universal design in assessing health care experiences. Med Care 2002;40:725-8.

78. Hesse BW. Curb cuts in the virtual community: telework and persons with disabilities. In: Proceedings of 28th Annual Hawaii International Conference on System Sciences, Maui HI, 1995:418-25.

79. Chiang MF, Starren J. Evaluation of consumer health website accessibility by users with sensory and physical disabilities. Medinfo 2004;11:1128-32.

80. Rudd RE, Comings JP, Hyde JN. Leave no one behind: improving health and risk communication through attention to literacy. J Health Commun 2003;8(suppl 1):104-15.

81. Rudd RE, Kaphingst K, Colton T, Gregoire J, Hyde J. Rewriting public health information in plain language. J Health Commun 2004;9:195-206.

82. Koyani S, Bailey RW, Nall JR. Research-based web design and usability guidelines. Bethesda MD: National Institutes of Health, 2003 (NIH publication 03-5424).

83. Shneiderman B, Plaisant C. Designing the user interface: strategies for effective human-computer interaction. 4th ed. Boston: Pearson/Addison Wesley, 2004

84. Kaphingst KA, Zanfini CJ, Emmons KM. Accessibility of web sites containing colorectal cancer information to adults with limited literacy (United States). Cancer Causes Control 2006;17:147-51.

85. Landauer TK. The trouble with computers: usefulness, usability, and productivity. Cambridge MA: MIT Press, 1995

86. Hesse BW, Werner CM, Altman I. Temporal aspects of computer-mediated communication. Computers Hum Behav 1988;4:147-65.

87. Poissant L, Pereira J, Tamblyn R, Kawasumi Y. The impact of electronic health records on time efficiency of physicians and nurses: a systematic review. J Am Med Inform Assoc 2005;12:505-16.

88. Zuboff S, Maxmin J. The support economy: why corporations are failing individuals and the next episode of capitalism. New York: Viking, 2002.

89. Eng TR. Emerging technologies for cancer prevention and other population health challenges. J Med Internet Res 2005;7:e30.

90. Detmer DE. Building the national health information infrastructure for personal health, health care services, public health, and research. BMC Med Inform Decis Mak 2003;3:1.

91. Deering MJ. Developing the health information infrastructure in the United States. Stud Health Technol Inform 2002;80:121-8.

92. Abrams DB. Applying transdisciplinary research strategies to understanding and eliminating health disparities. Health Educ Behav 2006;33:515-31.

93. Shneiderman B. Software psychology: human factors in computer and information systems. Cambridge MA: Winthrop Publishers, 1980.

94. Gladwell M. The tipping point: how little things can make a big difference. Boston: Back Bay Books, 2002. 